\title{
microRNAs Promoting Growth of Gastric Cancer Xenografts and Correlation to Clinical Prognosis
}

\author{
ULRICH H. WEIDLE ${ }^{1}$, FABIAN BIRZELE ${ }^{2}$ and ADAM NOPORA ${ }^{1}$ \\ ${ }^{1}$ Roche Pharma Research and Early Development, Roche Innovation Center Munich, Penzberg, Germany; \\ ${ }^{2}$ Roche Pharma Research and Early Development, Pharmaceutical Sciences, \\ Roche Innovation Center Basel, Basel, Switzerland
}

\begin{abstract}
The annual death toll for gastric cancer is in the range of 700,000 worldwide. Even in patients with earlystage gastric cancer recurrence within five years has been observed after surgical resection and following chemotherapy with therapy-resistant features. Therefore, the identification of new targets and treatment modalities for gastric cancer is of paramount importance. In this review we focus on the role of microRNAs with documented efficacy in preclinical xenograft models with respect to growth of human gastric cancer cells. We have identified 31 miRs ($10 b,-19 a,-19 b,-20 a,-23 a / b,-25,-27 a-3 p,-92 a,-93,-100$, $-106 a,-130 a,-135 a,-135 b-5 p,-151-5 p,-187,-199-3 p,-215$, $-221-3 p,-224,-340 a,-382,-421,-425,-487 a,-493,-532-3 p$, $-575,-589,-664 a-3 p)$ covering 26 different targets which promote growth of gastric cancer cells in vitro and in vivo as xenografts. Five miRs (miRs -10b, 151-5p, -187, 532-3p and -589) additionally have an impact on metastasis. Thirteen of the identified miRs $(-19 b,-20 a / b,-25,-92 a$, $106 a,-135 a,-187,-221-3 p,-340 a,-421,-493,-575$ and 589) have clinical impact on worse prognosis in patients.
\end{abstract}

Gastric cancer (GC) is the third-leading cause of cancer worldwide and is the forth most common cancer with an

This article is freely accessible online.

Correspondence to: Adam Nopora, Roche Innovation Center Munich, Roche Diagnostics GmbH, Nonnenwald 2, D-82372 Penzberg, Germany. Tel: +49 8856602552, e-mail: adam.nopora@roche.com and Ulrich H. Weidle, Roche Innovation Center Munich, Roche Diagnostics GmbH, Nonnenwald 2, D-82372 Penzberg, Germany. Tel: +49 8856602552, e-mail: weidle49@t-online.de

Key Words: Apoptosis, migration, invasion, proliferation, clinical prognosis, gastric cancer xenograft models, microRNA targets and inhibitors, tumor growth and metastasis, review. annual death toll of 700,000 worldwide (1). Intestinal-type and diffuse-type are the major histological subtypes (2). A total of $90 \%$ of GCs are adenocarcinomas which arise from the glandular epithelium (1). A total of $1-3 \%$ of GCs are hereditary cancers due to inactivating mutations in E-cadherin (1). From a molecular point of view, the following subtypes have been defined: Epstein-Barr-Virus (EBV)-positive with pronounced DNA hypermethylation, genomic stable subtype with distinctive genomic alterations, the microsatellite instability subtype (MSI) and the chromosomal instability (CIN) subtype characterized by aneuploidy and focal amplification of transmembrane receptor tyrosine kinases (3). These subtypes are correlated with different survival and outcomes of chemotherapy (3). Several agents have been approved for the treatment of gastric cancer: chemotherapybased drugs such as 5-fluorouracil (5-FU)-related agents, docetaxel, doxorubicin and mitomycin $\mathrm{B}$ as well as monoclonal antibodies (mABs) such as trastuzumab (HER2 as a target) for HER2-positive patients, ramicurumab (VEGFR2 as a target) and checkpoint-inhibitory antibody pembrolizumab directed against programmed cell death 1 (PD1) (5-10). Nevertheless, in patients with early-stage GC, recurrence within 5 years after surgical resection and subsequent chemotherapy has been observed $(4,5)$. The prognosis of patients with advanced GC is significantly worse $(4,5)$.

Therefore, the identification of new targets and treatment modalities is an important issue. In this review, we describe the role of microRNAs (miRs) in pathogenesis and metastasis of GC. We focus on miRs which are up-regulated in GC tissue in comparison to matching normal tissues which exhibit efficacy in preclinical in vivo models. We have excluded: miRs playing a functional role in Helicobacter pylori-related gastric cancer models, miRs exerting their function by interaction with non-coding RNAs, miRs delivered by exosomes and those induced in tumor cells by stromal cells. 


\section{microRNAs and Their Role in Oncology}

miRs are double-stranded non-coding RNAs comprising 2225 nucleotides (nts) which are generated from precursors transcribed in the nucleus, processed and finally 22-25 nts miR complexes are released into the cytoplasm (12-14). The guide strand is maintained and the other strand, the passenger strand, is degraded $(13,14)$. A single miR species may repress several miRs and each mRNA can be degraded by several different miRs indicating their potential to modulate serveral pathways and cellular networks (15). miRs can be transcribed from single transcriptional units or from multicistronic transcripts from a coding gene, introns or noncoding genes (15).

In oncology, miRs function as oncogenes as well as tumor suppressors (TS), depending on the cell-type in which they are expressed (15-17). Genetic deletion of the miR-15/16 genetic locus in mice recapitulated the features of human chronic lymphocytic leukemia, supporting their role as tumor suppressors (18). An oncogenic role was identified for miR221 which induced hepatocellular carcinomas in transgenic mice after liver-specific expression (19). miRs are also involved in metastasis. We have recently summarized their role in metastasis in breast-, prostate, ovarian, lung and pancreatic cancer (20).

\section{miRs Inhibiting Tumor Suppressors}

PTEN. miRs-221-3p (25), -382 (26), -425 (27) and -575 (28) (Figure 1) target phosphatase and tensin homolog PTEN which dephosphorylates phosphatidylinositol-3,4,5 triphosphate and thus negatively regulates the AKT signaling pathway $(29,30)$. miRs -382 and -425 are induced by hypoxia-inducible factor 1 (HIF-1) or interleukin $1 \beta$ (Il1 $\beta$ ), respectively $(26,27)$. miRs-221-3p, $-382,-425$ and -575 affect tumor growth of gastric cancer cell lines SNU-1, MKN1, NCI-N87 and MGC-803 respectively after subcutaneous implantation into nude mice (25-28). miR-382 also affects angiogenesis, by promoting sprouting, branching and network formation of blood vessels induced by vascular endothelial growth factor (VEGF) (26). Overexpression of miRs-221-3p and -575 in GC patients in comparison to matching normal tissues correlates with worse prognosis $(25,28)$. All the discussed miRs activate AKT signaling. Data derived from The Cancer Genome Atlas (TGCA) show that miR-221 is overexpressed in GC tissues in comparison to matching normal tisses (Figure 2).

RASSF 8. miR-224 (Figure 1) is induced by hypoxia and increases cell viability and invasion in gastric cancer cell lines SGC-7901 and MGC-803 (31). SCG-7901 cells transfected with a miR-224 antagomir exhibit reduced growth after subcutaneous implantation into nude mice (31).
Ras-association domain containing protein 8 (RASSF8) was identified as a direct target of miR-224 (32). RASSF8 is a member of a family of 10 genes which are linked to processes such as cell proliferation, cell death and responses to hypoxia (32). The above mentioned in vitro effects were recapitulated by overexpression of RASSF8 in SGC-7901 and MGC-803 cells (31). RASSF8 overexpression inhibits nuclear factor $\mathrm{kB}(\mathrm{NFkB})$ signaling and it functions as a TS $(33,34)$.

\section{microRNAs Targeting Transcription Factors}

miR-187 (FOXA2). Increased expression of miR-187 (Figure $1)$ is associated with clinico-pathological features and prognosis in GC patients (35). miR-187 promotes proliferation, migration and invasion of SGC-7901 GC cells (35). SGC-7901 cells overxpressing miR-18 exhibit increased tumor growth (TG) after subcutaneous implantation into nuce mice and increased lung colonization after tail vein injection (35). Forkhead box protein A2 (FOXA2) was identified as a direct target of miR-187 (35). It was shown that FOXA2 mediates the biological functions of miR-187 (35). FOXA2 is a transcriptional factor which suppresses gastric carcinogenesis in vitro and in vivo (36).

miR-199-3p (ZHX1). miR-199-3p increases proliferation and suppresses apoptosis in vitro and in vivo of GC cell lines SGC-7901 and NCI-N87 (37) (Figure 1). Transcription factor zinc fingers and homeoboxes (ZHX1) was identified as a target for miR-199-3p (37). Restoring ZHX1 expression in SGC-7901/miR-199-3p cells inhibits cell proliferation induced by miR-199a-3p (37). It has been shown that ZHX1 inhibits GC cell growth through inducing cell-cycle arrest and apoptosis (38). The ZHX family consists of three members containing two Cys2His2 zinc finger domains and five homeobox DNA-binding motifs (39).

RUNX1 and RUNX3. miRs-215 and -532-3p (Figure 1) target runt-related transcription factors RUNX1 or RUNX3 respectively $(40,41)$. Ectopic expression of miR-215 promotes migration and invasion of GES-1 and HGC-27 cells (35). RUNX1 could partially reverse the function of miR-215 (35). HGC-27 cells stably expressing miR-215 metastasize to the liver after intraperitoneal injection (40). miR-532-5p promotes growth and migration of BGC-823 gastric cancer cells (36). In vivo miR-532-3p promotes lung colonization after tail vein injection of BCG-823 gastric cancer cells transfected with miR-532-3p (41). The RUNX familiy of transcription factors are frequently inactivated in cancer and function as TS (42). RUNX1 plays a role in early steps of haematopoesis and acts as a TS in breast cancer (43). RUNX3 was shown to have a tumor- and metastasis suppressive role in GC (44-47). 
A

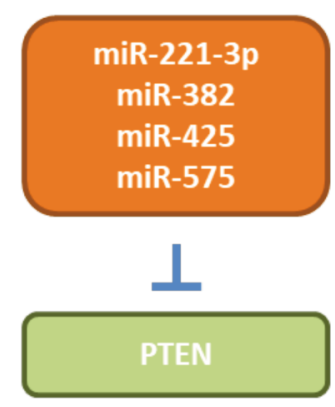

B

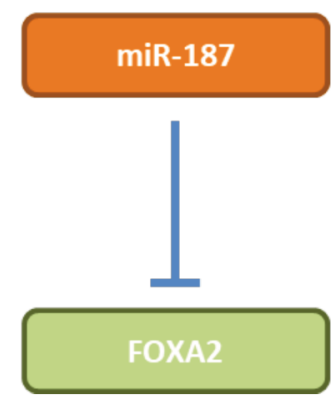

miR-224
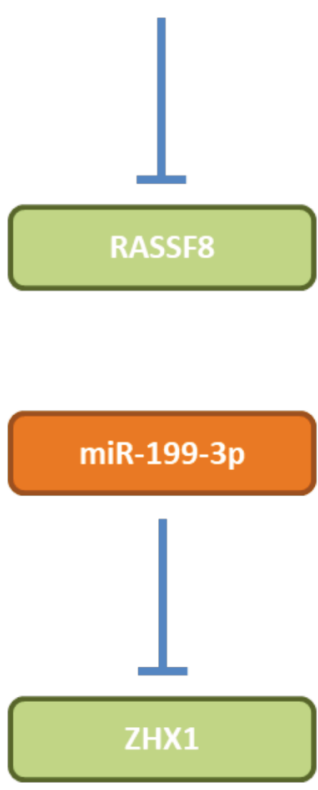

$\operatorname{miR}-215$ miR-532-3p

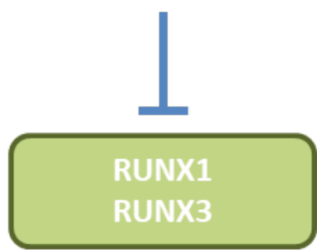

Figure 1. Up-regulated miRs mediating efficacy in gastric cancer-related in vivo models. miRs and the corresponding targets are shown. (A): miRs targeting tumor suppressor genes. PTEN: Phosphatase and tensin homolog; RASSF8: ras association domain-containing protein 8. (B): miRs targeting transcription factors. FOXA2: Forkhead-box-protein A2; RUNX1: runt-related transcription factors 1 and 3; ZHX1: zinc fingers and homeoboxes protein 1.

\section{miRs Targeting Ubiquitin-related Enzymes}

$m i R-25$. miR-25 (Figure 3A) is overexpressed in primary tumor tissues of GC patients and is significantly correlated with a more aggressive phenotype of GC in patients (48). miR-25 mediates proliferation, invasion and migration of GC in vitro and promotes TG in vivo (48). F-box/WD repeat containing protein 7 (FBXW7) was identified as a direct target of miR-25 (48). Restauration of expression of FBXW7 led to reversion of the described in vitro effects (48). F-box proteins constitute one of the four subunits of the ubiquitinprotein ligase system $(49,50)$. FBXW7 has been shown to function as a TS of human tumorigenesis (51). Data from TCGA show that miR-25 is over-expressed in GC tissues in comparison to matching normal tissues (Figure 2).

$m i R-100$. Expression of miR-100 (Figure 3A) correlates with GC tumorigenesis and progression (52). Inhibition of miR100 results in apoptosis of poorly differentiated gastric cancer cells, but not of non-cancerous gastric cells in vitro and in vivo (52). RNF144B, an E3-ubiquitin ligase was identified as a direct target of miR-100. RNF144B contains a single transmembrane domain close to the C-terminus, is localized in the nucleoli and mitochondria and promotes apoptosis under various cell damaging events by degradation of p53 (53-55).

\section{miRs Targeting Transmembrane Receptors}

$m i R-106 a$. miR-106a (Figure 3B) expression is significantly associated with tumor size, lymphatic and distant metastasis (56). miR-106 inhibits apoptosis of GC cells AGS, N87 and BGC823 (56, 57). FASR (CD95) and caspase 3 were identified as direct targets of miR-106 (56, 57). MicroRNA-106a functions as an oncogene in human gastric cancer and contributes to proliferation and metastasis in vitro and in vivo. miR-106 inhibits GC cell apoptosis through a FASR (CD95)-mediated, extrinsic cell death pathway (56-59). Data derived from TCGA show that miR-106a is over-expressed in GC tissues in comparison to matching normal tissues.

$m i R-421$. miR-421 (Figure 3B) is increased in GC and is associated with poor prognosis (60). An antagomir of 421 reduces TG of subcutaneously implanted SGC-790/1 cells in nude mice (60). E-Cadherin and caspase 3, key regulators in the process of epithelial mesenchymal transition (EMT) have been identified as targets of miR-421 (60-62). Data derived 


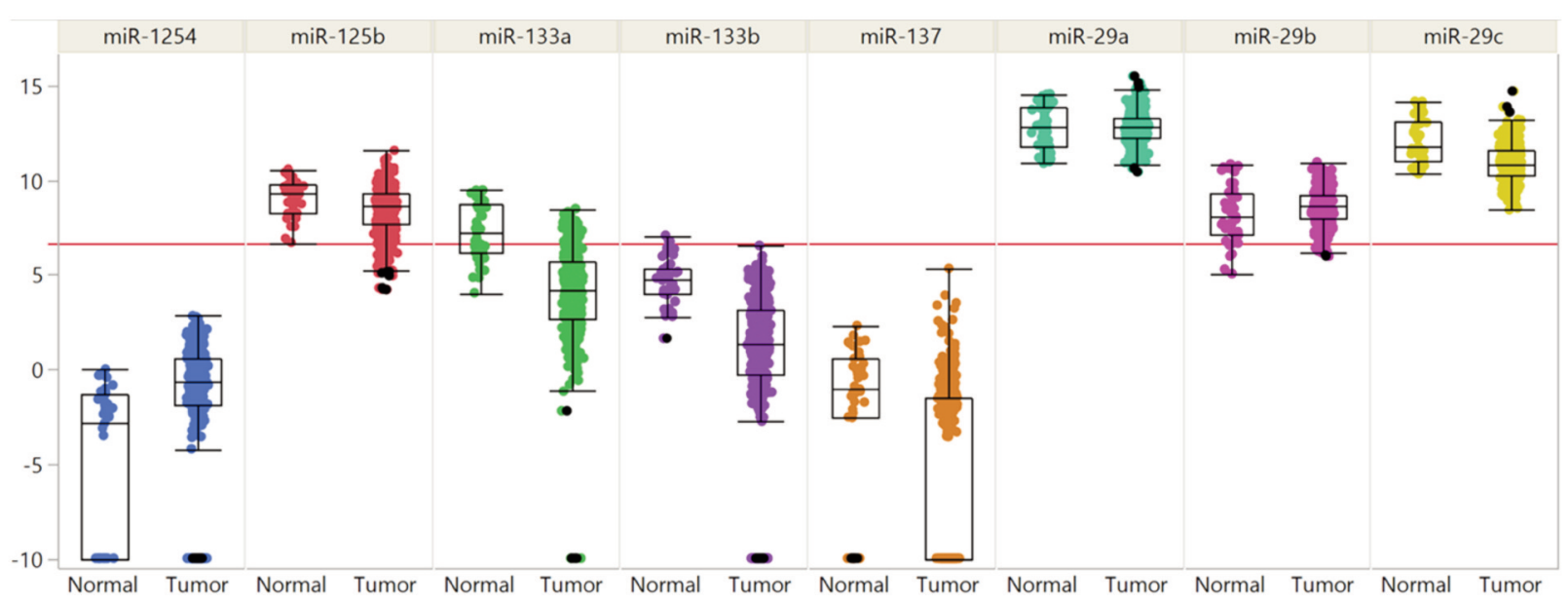

Figure 2. Expression of selected miRs in stomach adenocarcinoma compared to normal tissues. Data are shown for miR-106a, miR-19b, miR-20a, miR-20b, miR-221, miR-25, miR-340, miR-421, miR-493, miR-589 and miR-92a. Data from 436 tumor samples and 41 normal stomach samples derived from The Cancer Genome Atlas are shown. miR expression was quantified by RNA sequencing and is shown as log 2 of normalized read counts. The red lines indicate lower versus higher expression. Expression data are shown as box plots. The line in the medium of the box represents the median value, the rectangles show the upper and lower 25\% quartiles, and 50\% of all data points are included in the greater rectangle. All data points, except for the outliers are located within the upper and lower whiskers.

from TCGA show that miR-421 is over-expressed in GC tissues in comparison to matching normal tissues.

miR-589. miR-589 (Figure 3B) is up-regulated in GC tissues and associated with poor prognosis in patients with GC (63). miR-589 induces migration and invasion of GC cell lines MGC803 and BCG823 in vitro (63). Endogenous overexpression of miR-589 promotes lung metastasis of MGC-803 cells after tail vein injection (63). Leukemia inhibitory factor receptor (LIFR) was identified as a direct target of miR-589 (63). LIFR suppresses the in vitro effects of miR-589 as described above (63). It was shown that LIFR is essential for miR-589-mediated promotion of PI3K/AKT signaling activation (63). LIFR (CD118) is a low-affinity subunit of the LIFR and together with a highaffinity converter subunit binds leukemia inhibitory factor (LIF) with high affinity. LIF is an interleukin 6 (IL6) class cytokine (64). LIFR has been identified as a metastasis suppressor in hepatocellular carcinoma (65). Data derived from TCGA atlas confirm that miR-589 is over-expressed in GC tissues in comparison to corresponding normal tissues (Figure 2).

\section{miRs Involved in Signaling Pathways}

miR-19a. mi-19a (Figure 4) promotes proliferation and tumorigenicity of MGC-803 and SGC-7901 GC cells (66). In vivo, increased TG was noted with SGC-7901 cells overexpressing miR-19a after subcutaneous implantation
(66). Suppressor of cytokine signaling-1 (SOCS-1) was identified as a direct target of miR-19a (66). miR-19a expression levels are inversely correlated with SOCS-1 levels in GC tissues (66). SOCS-1 is member of a family of eight proteins each of which contains a src hmology 2 (SH2) domain and a COOH-terminal SOCS-box (67). SOCS-1 functions as an inhibitor of the janus tyrosine kinase (JAK) and signal transducer and activator of transcription 3 (STAT3) pathways $(68,69)$.

$m i R-19 b,-20 a, 92 a$. miRs-19b, -20a and 92a (Figure 4) are members of the mir-17-92 cluster and are overexpressed in human GC stem cells and are negatively correlated with the survival of GC patients (70). SGC7901 cells transduced with miRs-19b, $-20 \mathrm{a}$ or $-92 \mathrm{a}$ show improved TG after subcutaneous implantation into nude mice (70). Transcription factor E2F1 and homeodomain-interacting protein kinase (HIPK) were identified as targets of the miRs of the miR-1792 cluster which are involved in self-renewing of GC stem cells (70). E2F can activate transcription of $\beta$-catenininteracting protein (ICAT), an inhibitor of $\beta$-catenin (71). HIPK1 phosphorylates homeodomain transcription factors and co-repressors of homeobox transcriptions factors and modulates $\beta$-catenin signaling by interaction with dishevelled, a multi-domain scaffold protein required for virtually all WNT signaling activities (72). Data derived from the TCGA show that miRs-19b, -20a and $-92 a$ are overexpressed in GC tissues in comparison to corresponding normal tissues (Figure 2). 


\section{A}
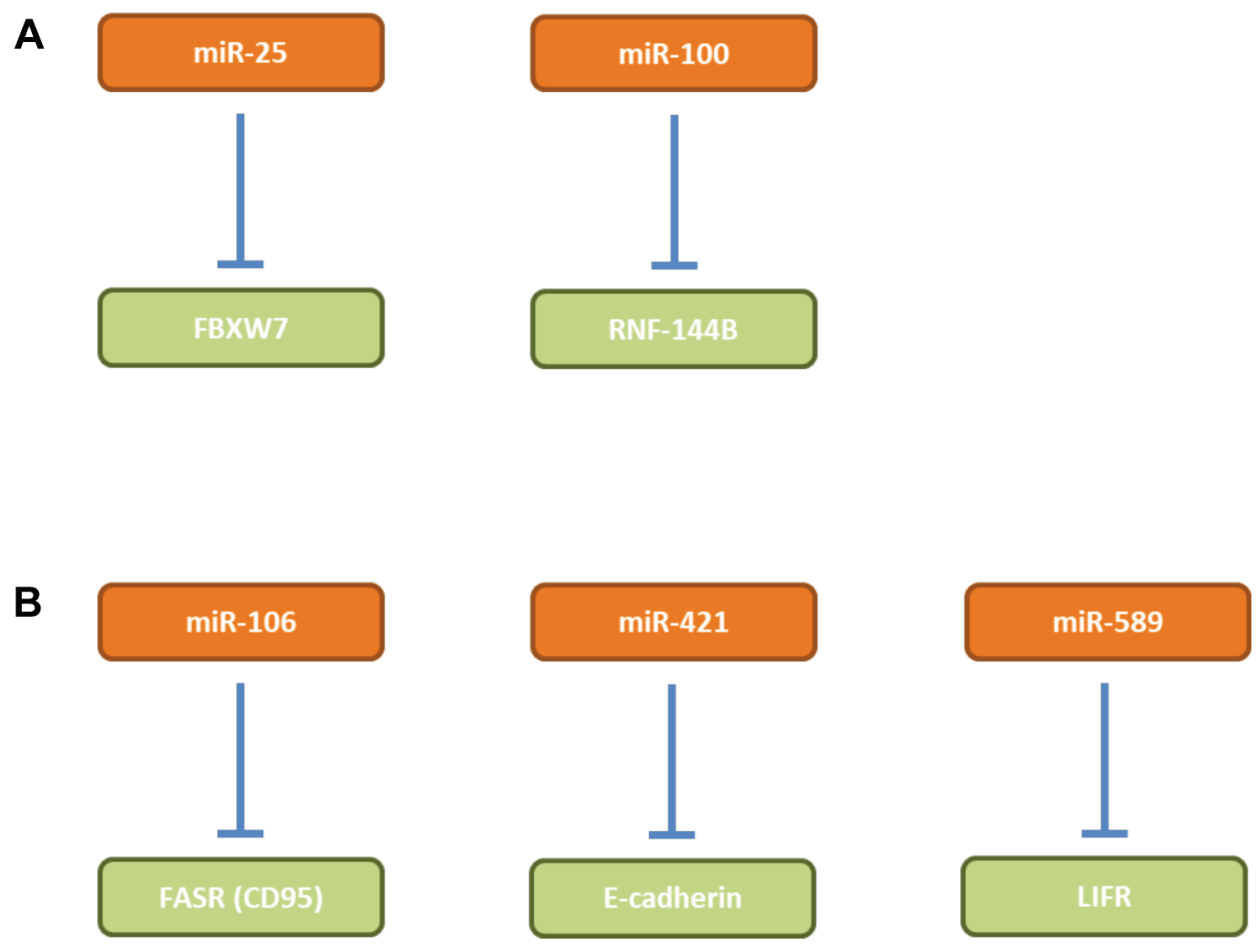

Figure 3. Up-regulated miRs mediating efficacy in gastric cancer-related in vivo models. (A): miRs targeting ubiquitinylation related mRNAs. FBXW7: F-box/WD repeat-containing protein 7; RNF144B: ring finger protein 144B. (B): miRs targeting transmembrane receptors. CD95: cluster of differentiation 95; FASR: FAS receptor; LIFR: leukemia inhibitory factor receptor.

miR-493. miR-493 (Figure 4) is up-regulated in GC and promotes proliferation of SGC-709 and MGC-803 GC cells (73). TG of MGC-803 GC cells overexpressing miR-493 is increased after subcutaneous implantation in comparison to the control cell line (73). Dickkopf-related protein-1 (DKK-1) has been identified as direct target of miR-493 (73). Ectopic expression of DKK-1 can rescue the effect of a miR-493 inhibitor on proliferation in vitro and TG in vivo (73). DKK1 is an antagonist of the WNT/ $\beta$-catenin signaling pathway by isolating the low-density lipoprotein receptor-related protein 6 (LRP6) co-receptor so that it can not aid in activating the WNT signaling pathway $(74,75)$. High DKK-1 expression regardless of $\beta$-catenin positivity is a crucial prognostic factor for predicting tumor recurrence and survival of patients with resected advanced GC (76). Data derived from TCGA show that miR-493 is over-expressed in GC tissues in comparison to corresponding normal tisses (Figure 2).

$m i R-664 a-3 p$. miR-664a-3p (Figure 4) is up-regulated in GC tissues and promotes GC cell proliferation (77). miR-664a-3p mimics promote tumor volume of SGC790 and HGC27 GC tumor cells subcutaneously injected into nude mice, wheras a miR-664a-3p inhibitor decreases the tumor volume (77). MOB kinase activator $1 \mathrm{~A}(\mathrm{MOB} 1 \mathrm{~A})$ was identified as a direct target of miR-664a-3p (77). MOB1A is a component of the Hippo pathway which is involved in restraining cell proliferation and promoting apoptosis. The Hippo pathway is frequently deregulated in different human cancers, but most Hippo pathway genes are not commonly mutated (78-80). MOB1A inhibits large tumor suppressor kinases 1 and 2 (LATS 1/2) which modulates two other kinases, nuclear dbf2-related 1 and 2 (NDR1 and NDR2) resulting in enrichment of yes-associated protein-1 (YAP) and transcriptional activator with PDZ-binding motif (TAZ) in the nucleus leading to a negative impact on transcription of Hippo pathway-related genes (78-80).

\section{micro-RNAs Modulating Apoptosis}

$m i R s-23 a / b,-93$. miRs-23a/b and -93 (Figure 4) are upregulated in GC tissues in comparison to normal tissues (81, 82). Programmed cell death 4 (PDCD4) has been identified as a direct target of miRs-23a/b and $-93(81,82)$. Introduction of miR-23a/b mimetics into MKN-45 and AGD GC cells reduces PDCD4 levels, whereas miR-23a/b antisense oligonucleotides increase PDCD4 levels (81). AGS cells transfected with PDCD4 small interfering RNA (siRNA) showed decreased apoptosis, transfection of a PDCD4 expression plasmid had the opposite effect (82). In 

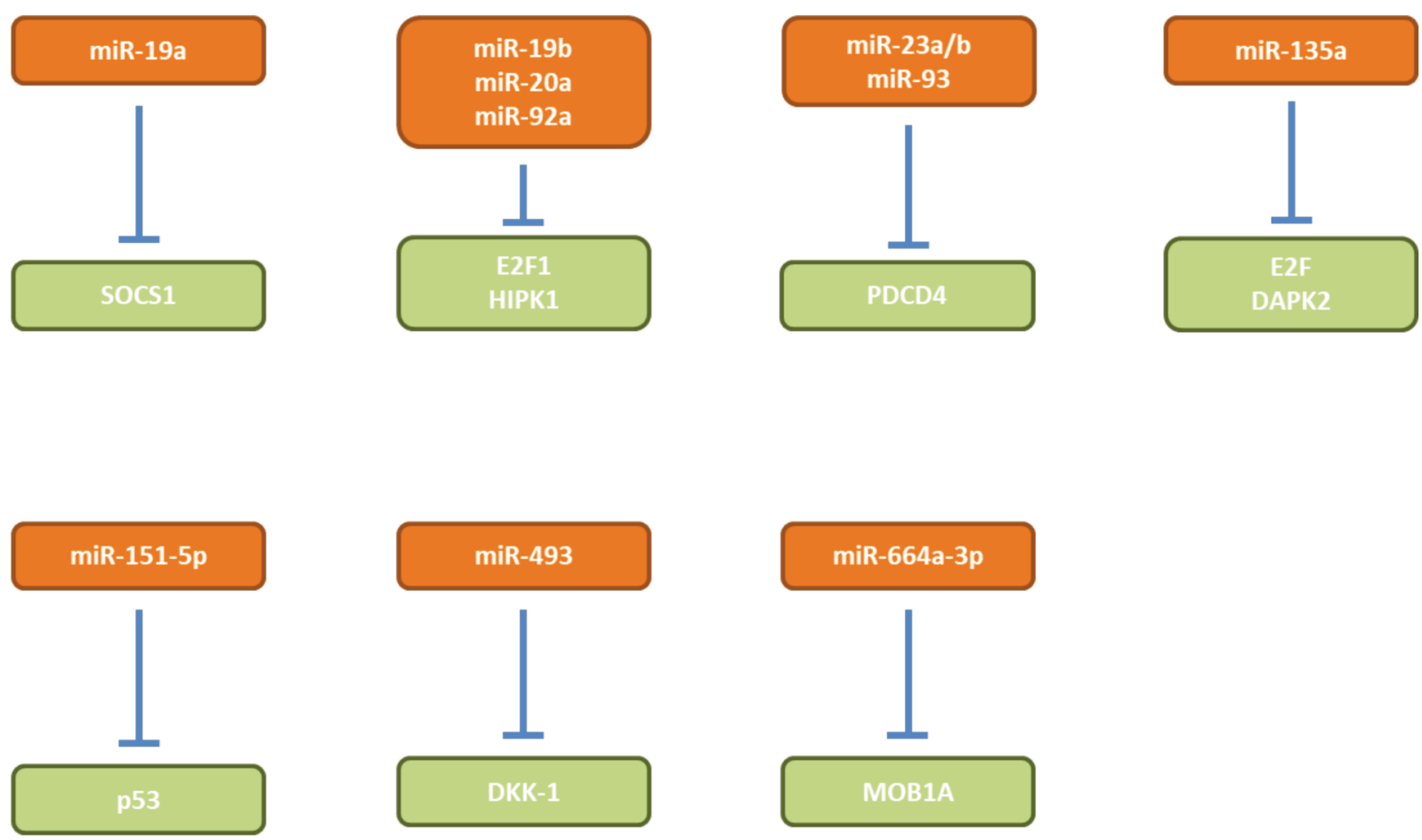

Figure 4. Up-regulated miRs mediating efficacy in gastric cancer-related in vivo models targeting signaling-and apoptosis-related pathways. DAPK2: Death-associated protein kinase 2; DKK-1: dickkopf-related protein-1; E2F: transcription factor E2F; HIPK: homeobox-interacting protein kinase; MOB-1A: MOB kinase activator A; p53: protein 53; PDCD4: programmed cell death protein 4; SOCS1: suppressor of cytokinase signaling 1.

vivo, MKN-45 and AGS GC cells overexpressing miR-23a/b or miR-93 respectively, exhibited increased tumor size and weight after subcutaneous implantation into immunocompromized mide $(81,82)$. PDCD4 mediates sensitivity to apoptosis by suppressing FLICE inhibitory protein (FLIP), a negative regulator of apoptosis $(83,84)$. Down-regulation of PDCD4 has been observed in tumorigenesis and progression of human digestive cancers (85). In gastric GC, PDCD4 has been identified as a TS gene (86).

miR-135a. mR-135a (Figure 4) is up-regulated in GC patients and is associated with poor prognosis (87). miR135a correlates with resistance to oxaliplatin (OXA) (87). OXA-resistant GC cells proliferate in response to miR-135a expression (87). TG of MGC-803/OXA GC transfected with miR-135a was increased and TG was reduced with MGC803/OXA cells transfected with a miR-13 functional inhibitor after subcutaneous implantation into nude mice (87). E2F1 and death-associated protein kinase 2 (DAPK2) were identified as direct targets of miR-135a, promoting OXAresistance (87). DAPK2 is stimulated by E2F1 and induces apoptosis by the kruppel-like factor (KLF/Sp1) transcription factor pathway (88). Restoration of DAPK2 TS in cancer cells by fusion protein containing a tumor-targeting module and DAPK2 reconstitution is a therapeutic strategy to selectively induce apoptosis in cancer cells $(89,90)$. In patients with GC hypermethylation of the DAPK gene has been observed (91).

miR-151-5p. miR-151-5p (Figure 4) expression is increased by activated Notch1 pathway (92). miR-151 promotes growth of SC-M1 GC cells and induces focal adhesion kinase (FAK) (92). SC-M1 cells overexpressing miR-151-5p exhibit augmented tumor sizes in comparision to control cells after subcutaneous implantation into nude mice (92). After tail vein injection of these cells, metastatic nodules in the lungs were significantly increased (92). p53 was identified as a target of miR-151-5p (92). The apoptosismediating function of p53 in cancer is well documented $(93,94)$. The suppressive effects of miR-151 antagomirs on Notch1 signalling-induced metastasis of SC-M1 cells could be partially recovered by cotransfection of an siRNA vector against p53 (92).

\section{microRNAs Interfering With the Cell-Cycle}

$m i R-27 a-3 p$. miR-27a-3p (Figure 5A) is over-expressed in GC tissues and promotes proliferation and TC growth in NCI-N87, 
A

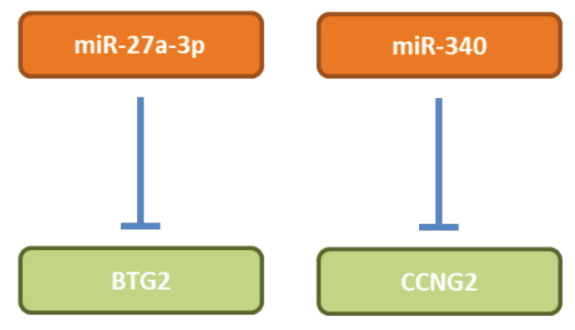

B
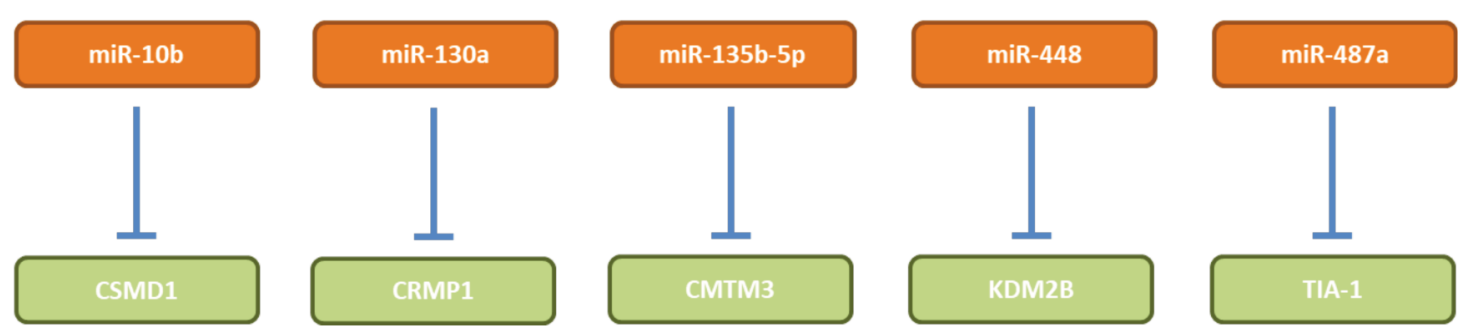

Figure 5. Up-regulated miRs mediating efficacy in gastric cancer-related in vivo models. (A): miRs targeting cell-cycle-related proteins. BTG2: BTG family member 2; CCNG2: cyclin-G2. (B): miRs interfering with other targets. CMTM3: CKLF like MARVEL transmembrane domain containing 3; CRMP1: collapsin response mediator protein 1, CSMD1: CUB and sushi multiple domains 1; KDM2B: Lysine (K)-specific demethylase 2B; TIA-1: T cell intracellular antigen-1.

MGC-803 and GES-1 GC cells (95). Ectopic expression of miR-27a-3p in GES-1 cells promotes tumor weight and volume after subcutaneous administration into immunodeficient mice, the opposite holds true for MGC-803 cells with inhibited expression of miR-27a-3p (95). B-cell translocation gene (BTG2) has been identified as a direct target of miR-27a3p (95). BTG2 induces apoptosis and triggers cell cycle arrest by inhibiting G1/S transition $(96,97)$. BTG2 is frequently deleted or mutated in B-cell malignancies and functions as a TS in several types of tumors (98).

miR-340. miR-340 (Figure 5A) is up-regulated in GC tissues and cell lines (99). Elevated expression of miR-340 is correlated with adverse clinicopathological features and poor prognosis in GC patients (99). miR-340 promotes motility, proliferation and cell-cycle progression of GC cells such as SGC-7901 and MGC-803 (99). Inhibition of miR-340 decreased TG of MGC-803 cells in nude mice and cyclin G2 was identified as a direct target of miR-340 (99). CCNG2 is critical for the functional effects of miR-340 in GC cells, because knockdown of CCNG2 abrogated the effects of miR-340 knockdown in MGC-803 cells (99). CCNG2 is a regulator of cell proliferation and induces $\mathrm{G} 1 / \mathrm{S}$ phase cell cycle arrest $(100,101)$. CCNG2 expression is decreased in GC (102). Based on data derived from TCGA, miR-240 is over-expressed in GC tissues in comparison to matching normal tissues (Figure 2).

\section{Other miRs Affecting Growth of Gastric Cancer}

miR-10b. miE-10b (Figure 5B) promotes proliferation, invasion, colony formation and EMT of HGC27 GC cells (103). MKN74 cells overexpressing miR-10b show increased tumor volume and weight and metastasis to the liver after subcutaneous implantation in nude mice (103). CUB and sushi multple domains 1 (CSMD1) was identified as a target of miR-10b (103). Expression of CSMD1 was negatively correlated with expression of miR-10b in GC tissues (103). Inhibition of CSMD1 leads to activation of the $\mathrm{NFKB}$ pathway resulting in up-regulation of cyclin D1 (CCND1) and EMT markers (103). CSMD1 is a single membrane spanning protein which contains $14 \mathrm{~N}$-terminal CUB domains that are separated from each other by a SUSHI domain followed by an additional 15 tandem SUSHI domain segment and functions as a complement inhibitor (104). In melanoma cells, CSMD1 exhibits anti-tumor activity by inhibiting cell-cycle progression and apoptosis via the SMAD pathway (105). Loss of CSMD1 has been observed in head-and-neck squamous cell carcinoma, lung- and breast cancer (106). 
miR-130a. miR-130a (Figure 5B) is elevated in GC cell lines (107). In BGC823 cells, miR-130a promotes proliferation and inhibits cell-cycle arrest in G1 phase, colony formation, cell invasion and migration as well as cell adhesin by targeting collapse response mediator protein 4 (CRMP4) (107). CRMP4 reversed the in vitro effects of miR-130a as described above (107). miR-130a functions as an oncomir. miR-130a accelerates TG of BGC823 cells in nude mice and depletion of CRMP4 with small hairpin RNA (shRNA) results in retardation of TG (107). CRMPs are a family of five cytosolic proteins which are expressed in the nervous system during development and through interactions with microtubules play important roles in axon formation and growth cone guidance and collapse (108). They are implicated in proliferation, apoptosis, differentiation, progression and metastasis of tumors (109). In melanoma cells, CRMP1 plays an anti-tumoral role in cell-cycle regulation and controlling apoptosis via the SMAD pathway (110). It was shown that VEGF promotes GC development by up-regulation of CRMP4 (111).

miR-135b-5p. miR-135b-5p (Figure 5B) expression in GC tissues is significantly higher compared to normal tissues (112). SGC-7901 GC cells infected with a lentivurs expressing a miR-135b-5p inhibitor exhibit reduced proliferation, suppressed cell-cycle progression and invasiveness and promotion of apoptosis (112). In vivo, this cell line has characteristics of reduced tumor growth in nude mice (112). Chemokine-like factor (CKLF)-like MARVEL transmembrane domain-containg family member 3 (CMTM3) was identified as a direct target of miR-135b-5p (112). CMTM3 is member of a family of nine genes in humans of the chemokine-like factor gene family similar to the chemokine and transmembrane 4 superfamilies of signaling molecules (113). It was previously shown that CMTM3 inhibits GC cell growth through apoptosis and its knockdown promotes metastasis of GC cells via the STAT3/Twist1/EMT signaling pathway (114-116). CMTM3 also decreases epidermal growth factor receptor (EGFR) expression and EGFR-mediated tumorigenicity in GC (117). Altogether, CMTM3 functions as a TS in GC and CMTMs excert TS functions in additional types of cancers (118).

$m i R-448$. miR-448 (Figure 5B) is over-expressed in GC and is associated with poor survival (119). miR-448 promotes growth and carcinogenicity of MKN87 and SGC7901 GC cells in vitro and in vivo (119). Lysine (K)-specific demethylase 2B (KDM2B) was identified as a direct target of miR-448. Suppression of KDM2B promotes glycolysis in GC cells and miR-448 is a positive regulator of glycolysis (119). Inhibition of of KDM2B induces expression of transcription factor MYC and glycolysis (119). KDM2B removes methyl groups from $\mathrm{H} 3 \mathrm{~K} 36 \mathrm{me} 2$ and $\mathrm{H} 3 \mathrm{~K} 4 \mathrm{me} 3$ of histones and inhibits glycolysis of cancer cells which are addicted to glycolysis in contrast to differentiated cells which use mitochondrial oxidative phosphorylation for energy production (119). MYC is known as inducer of glucose uptake and lactate production in cancer cells (120). However, from a general point of view, one should keep in mind that KDM2B is a double-edged sword in the regulation of cancer development which can act in a context-dependent manner as a TS or as an oncogene (121).

$m i R-487 a$. miR-487a (Figure 5B) promotes proliferation and suppresses apoptosis of GC in vitro and knockdown of miR487a has opposite effects (122). miR-487a enhances growth of GC xenografts (122). T cell intracellular antigen-1 (TIA1) has been identified as a direct target of miR-487a (122). TIA-1 contains three RNA recognition domains, the latter two have been shown to be important for RNA binding and selectivity (123). TIA-1 alters both co-transcriptional and post-transcriptional RNA processing and binds to VEGF-A mRNA (124). Alternative splicing of VEGF induced by TIA1 influences the angiogenic capability of colorectal cancer (125). TIA-1 also acts as a stress-induced translational inhibitor localizing to stress granules containg polyA RNA (126). Alternative splicing, export and translational regulation have been shown to contribute to tumor formation and progression and these events are attractive targets for therapeutic intervention $(127,128)$.

\section{Technical Aspects}

Oncomirs can be inhibited at several stages of their generation: at the level of transcription by RNA Pol II or III, at the level of precursor cleavage by DICER and at the level of functional inhibition of mature RNA, resulting in mRNA degradation and functional repression (129). The latter is the most popular mode of intervention. miRs inhibit several mRNAs, wheras siRNA inhibits only one specific mRNA (130). siRNAs are 2123 nt RNA duplexes with two nts 3'-overhang fully complementary to mRNA, whereas miRs are 19-25 nts RNA duplexes with two nts 3'-overhang with complementary binding in the seed region (nts 2 to 7 at the 5'-end) of the corresponding miR to the 3'-UTR of the mRNA (130). siRNA mediates endonucleolytic cleavage of the corresponding mRNA, wheras miRs preferentially induce degradation of mRNAs and translational repression $(129,130)$.

Anti-miR-oligonucleotides (AMO) are designed to bind a sequence complimentary to mature miRs. Incorporation of a phosphoro-thioate backbone and ribose 2'-OH modification (2'-F, 2'-O-methyl, 2'-O-methoxyethyl) have improved binding and pharmaco-kinetic and pharmako-dynamic properties of AMO's (130). Anti-miRs with a 2'-Omethoxyethyl modification are referred to as antagomirs. Also, incorporation of locked nucleic acids (LNA) which 
contain an additional bridge between the 2'-oxygen and the 4 '-carbon of the pentose have significantly improved the drug-like properties of AMO's (131).

Peptide nucleic acids (PNA) are under evaluation as miRinhibitory agents (132). In these agents the deoxy-phosphate backbone of nucleic acids is replaced by a polyamide chain of N-aminoethyl-glycyl units to result in polymers with an artificial backbone structure as a main chain with similarity to DNA or RNA (132). PNAs are resistant to nucleases, have stronger affinity and greater specificity for DNA and RNA than natural nucleic acids (132).

Identification of small molecule inhibitors of miRs is under active investigation. Several inhibitors which inhibit transcription of defined miRs have been identified, however specificity issues and target deconvolution of the identified compounds have to be tackled (133). Identification of compounds which target secondary elements in human miR hairpin precursors have been reported (134). It has been shown that a secondary structure of pre-miRs contains a narrow groove to which a positively charged compound can bind at nM affinity, making it a druggable candidate (135). Combination of bioinformatics and high throughput screening has revealed compounds which inhibit DICER cleavage sites in pre-miRs (136).

miR sponges are DNA constructs which contain artificially designed, tandemly reiterated miR-binding sites thus competing for miRs with the mRNA under consideration (137). They have to be transduced into the corresponding recipient cells (137). Furthermore, oncomirs have been knocked-out by making use of the genome-editing tool clustered regularly interspaced short palindromic repeats- CRISPR associated (CRISPR-CAS) $(138,139)$.

However, many additional issues have to be optimized case-by- case for optimization of therapeutic efficacy of miR-inhibitors. Extended circulation time by PEGylation [attachment of polyethylene glycol (PEG)] polymer chains attached to miRs has been achieved (140). Optimization of delivery is a crucial process for achieving therapeutic efficacy. Cationic complexes which interact with negatively charged RNA through electrostatic interactions have been created with synthetic polyethyleneimine (PEI) as early generation polymers for RNA delivery (141). Also, dendrimers, branched synthetic polymers are under evaluation as delivery agents $(142,143)$. Polymers also promote endosomal escape of miRs thus avoiding endosomal-lysosomal RNA degradation. Poly (lactic-coglycolic acid) (PLGA) is an FDA-approved synthetic biodegradable polymer for delivery of miR-inhibitors (144). Moreover, the use of cyclodextrins as delivery agents has been explored (145). Another class of delivery agents are lipid-based agents. These agents are composed of cationic lipids and liposomes which can form complexes with RNA through electrostatic interactions (146). Also, lipolyplexes composed of polymers and lipids are under investigation as delivery agents (147). Conjugation of miRs to specific ligands such as $\mathrm{N}$-acetylgalactosamine, a triantennary $\mathrm{N}$ acetylgalactosamine, high-affinity ligand specific for the asialoglycoprotein receptor, enhances potency of anti-sense oligonucleotides 6-10-fold in mouse liver (148). Several ciritical issues are not discussed in further details in this review such as toxicity issues, cytokine release syndrome, delivery into target tissues, efficient release of miR-related agents from endosomes, optimization of pharmaco-kinetic and pharmaco-dynamic properties, excretion by the kidneys and unspecific hybridization (149-155).

Synopsis. We have identified $31 \mathrm{miRs}$ covering 26 different targets which promote growth of GC cells in vitro and in vivo as xenografts. Five miRs (miRs -10b, 151-5p, -187, 532-3p and -589) additionally have an impact on metastasis. Thirteen of the identified miRs $(-19 b,-20 s,-25,-92 a,-106 a$, $-135 \mathrm{a},-187,-221-3 \mathrm{p},-340 \mathrm{a},-421,-493,-575$ and -589 correlate with worse prognosis in GC patients. The oncomirs identified are up-regulated in GC tissues, the corresponding targets are down-regulated. The homogeneity of expression of the target candidates miRs should be investigated in more details. As outlined previously GC patients have a high relapse rate after surgical resection and following chemotherapy. It would be of interest to investigate, whether inhibition of any of the identified miRs has an impact on established metastases in preclinical in vivo models.

\section{miRs Landscape Cancer}

miR-related therapeutics may be particulary suited for complex, multigenic disorders such as cancer, since they can interfere with several pathways. The first micro-RNA based therapeutic evaluated in clinical studies in cancer patients was MRX-34 by Mirna Therapeutics $(156,157)$. MRX-34 is an intra-venously injected liposomal formulation of a miR34 mimetic. miR-34 acts as a TS and inhibits proliferation, invasion by inhibition of WNT, NOTCH, TGF $\beta$ and EMTrelated transcription factors $(156,157)$. Repression of miR34 target genes such as forkhead box protein P1 (FOXP1), B-cell lymphoma 2 (BCL2), histone deacetylase 1 (HDAC1) and cyclin B1 (CTNNB1) was demonstrated in cancer patients, however, clinical studies were halted due to multiple immune-related side effects $(156,157)$. Another agent is a miR-16-based mimetic which is administered as EGFR-conjugated bacterial mini-cells (158). The agent was intra-venously injected into recurrent patients with malignant pleural mesothelioma with signs of radiologic progression after chemotherapy (NCI02369198). Twenty-two patients were enrolled and one objective response (5\%), in 15 patients $(68 \%)$ stabilisation of disease and in 6 patients (27\%) progression of disease was observed with an 
acceptable safety profile (158). miR-16 preferentially targets BCL2 (159). Inhibition of miR-155 is pursued by miRagen. miR-155 acts oncogenically in many haematological diseases and its expression correlates with prognosis in lymphoma and leukemic diseases (160). Cobomersen is a 14 nucleotides mixed-type (deoxynucleotide plus LNA phosphorothioatebased oligonucleotide which inhibits proliferation of tumor cells and T-cell activation and simultaneously regulates JAK/STAT, MAPK/ERK and PI3K/AKT signalling (160). In 68 patients with cutaneous T-cell lymphoma (CTCL), acute T-cell leukemia/lymphoma (ATLL), diffuse B-cell lymphoma (DBCL) and chronic lymphpcytic leukemia (CLL) cobomersen was administered for 2 years, reversion of the disease genetic signature and no serious side effects were observed (www.miragen.com). In CTLL patients cobomersen has reduced lesion severity after i.v. injection in a Phase I study. It remains to be seen whether miR-based therapeutic agents have a bright future in the space of cancer therapy.

\section{Conflicts of Interest}

AN and FB are employees of Roche; UHW was an employee of Roche.

\section{Authors' Contributions}

AN and UHW: design and writing of the paper; FB: bio-informatic analysis.

\section{References}

1 Van Cutsem E, Sagaert X, Topal B, Haustermans K and Prenen H: Gastric cancer. Lancet 388: 2654-2664, 2016. PMID: 27156933. DOI: $10.1016 / \mathrm{S} 0140-6736(16) 30354-3$

2 Hu B, El Hajj N, Sittler S, Lammert N, Barnes R and MeloniEhrig A: Gastric cancer: Classification, histology and application of molecular pathology. J Gastrointest Oncol 3: 251-261, 2012. PMID: 22943016. DOI: 10.3978/j.issn.2078-6891.2012.021

3 Sohn BH, Hwang JE, Jang HJ, Lee HS, Oh SC, Shim JJ, Lee KW, Kim EH, Yim SY, Lee SH, Cheong JH, Jeong W, Cho JY, Kim J, Chae J, Lee J, Kang WK, Kim S, Noh SH, Ajani JA and Lee JS: Clinical significance of four molecular subtypes of gastric cancer identified by the cancer genome atlas project. Clin Cancer Res 23: 4441-4449, 2017. PMID: 28747339. DOI: 10.1158/1078-0432.CCR-16-2211

4 Venerito M, Link A, Rokkas T and Malfertheiner P: Review: Gastric cancer-clinical aspects. Helicobacter 24(Suppl 1): e12643, 2019. PMID: 31486238. DOI: 10.1111/hel.12643

5 Orditura M, Galizia G, Sforza V, Gambardella V, Fabozzi A, Laterza MM, Andreozzi F, Ventriglia J, Savastano B, Mabilia A, Lieto E, Ciardiello F and De Vita F: Treatment of gastric cancer. World J Gastroenterol 20: 1635-1649, 2014. PMID: 24587643. DOI: 10.3748/wjg.v20.i7.1635

6 Bonelli P, Borrelli A, Tuccillo FM, Silvestro L, Palaia R, Buonaguro FM: Precision medicine in gastric cancer. World J Gastrointest Oncol 11: 804-829, 2019. PMID: 31662821. DOI: 10.4251/wjgo.v11.i10.804
7 Figueroa-Protti L, Soto-Molinari R, Calderón-Osorno M, Mora $\mathrm{J}$ and Alpízar-Alpízar W: Gastric cancer in the era of immune checkpoint blockade. J Oncol 2019: 1079710, 2019. PMID: 31662748. DOI: 10.1155/2019/1079710

8 Kwak Y, Seo AN, Lee HE and Lee HS: Tumor immune response and immunotherapy in gastric cancer. J Pathol Transl Med 54(1): 20-33, 2020. PMID: 31674166. DOI: 10.4132/jptm.2019.10.08

9 Akin T, Bregni G, Camera S, Deleporte A, Hendlisz A and Sclafani F: PD-1 and PD-L1 inhibitors in oesophago-gastric cancers. Cancer Lett 469: 142-150, 2020. PMID: 31669518. DOI: $10.1016 /$ j.canlet.2019.10.036

10 Hironaka S: Anti-angiogenic therapies for gastric cancer. Asia Pac J Clin Oncol 15: 208-217, 2019. PMID: 31111678. DOI: 10.1111/ajco.13174

11 Bartel DP: Metazoan microRNAs. Cell 173: 20-51, 2018. PMID:29570994. DOI: 10.1016/j.cell.2018.03.006

12 Slotwinski R, Lech $G$ and Slotwinska SM: microRNA in pancreatic diagnosis and therapy. Cent Eur J Immunol 43: 314324, 2018. PMID: 30588176. DOI: 10.5114/ceji.2018.80051

$13 \mathrm{Li} Z$ and Rana TM: Therapeutic targeting of microRNAs. Current status and future challenges. Nat Rev Drug Discov 13: 622-638, 2014. PMID: 25011539. DOI: 10.1038/nrd4359

14 Rupaimoole R and Slack FJ: MicroRNA therapeutics: towards a new era for the management of cancer and other diseases. Nat Rev Drug Discov 16: 203-222, 2017. PMID: 28209991. DOI: 10.1038/nrd.2016.246

15 Di Leva G, Garofalo M and Croce CM: MicroRNAs in cancer. Annu Rev Pathol 9: 287-314, 2014. PMID: 24079833. DOI: 10.1146/annurevpathol-012513-104715

16 Felli N, Fontana L, Pelosi E, Botta R, Bonci D, Facchiano F, Liuzzi F, Lulli V, Morsilli O, Santoro S, Valtieri M, Calin GA, Liu CG, Sorrentino A, Croce CM and Peschle C: MicroRNAs 221 and 222 inhibit normal erythropoiesis and erythroleukemic cell growth via kit receptor down-modulation. Proc Natl Acad Sci USA 102: 18081-18086, 2005. PMID: 16330772. DOI: $10.1073 /$ pnas. 0506216102

17 Garofalo M, Quintavalle C, Romano G, Croce CM and Condorelli G: miR221/222 in cancer: their role in tumor progression and response to therapy. Curr Mol Med 12: 27-33, 2012. PMID: 22082479. DOI: 10.2174/156652412798376170

18 Pekarsky Y and Croce CM: Role of miR-15/16 in CLL. Cell Death Differ 22: 6-11, 2015. PMID: 24971479. DOI: 10.1038/ cdd 2014.87

19 Callegari E, Elamin BK, Giannone F, Milazzo M, Altavilla G, Fornari F, Giacomelli L, D’Abundo L, Ferracin M, Bassi C, Zagatti B, Corrà F, Miotto E, Lupini L, Bolondi L, Gramantieri L, Croce CM, Sabbioni S and Negrini M: Liver tumorigenicity promoted by microRNA-221 in a mouse transgenic model. Hepatology 56: 10251033, 2012. PMID: 22473819. DOI: 10.1002/hep. 25747

20 Weidle UH, Dickopf S, Hintermair C, Kollmorgen F, Birzele F and Brinkmann U: The role of microRNAs in breast cancer metastasis: preclinical validation and potential therapeutic targets. Cancer Genomics Proteomics 15: 17-39, 2018. PMID: 29275360. DOI: $10.21873 / \operatorname{cgp} .20062$

21 Weidle UH, Birzele F, Kollmorgen G and Nopara A: Potential microRNA-related targets for therapeutic intervention with ovarian cancer metastasis. Cancer Genomics Proteomics 15: 115, 2018. PMID: 29275359. DOI: 10.21873/cgp.20061

22 Weidle UH, Epp A, Birzele F and Brinkmann U: The functional role of prostate cancer metastasis-related microRNAs. Cancer 
Proteomics 16: 1-19, 2019. PMID: 30587496. DOI: 10.21873/ cgp. 20108

23 Weidle UH, Birzele F and Nopora A: MicroRNAs as potential targets for therapeutic intervention with metastasis of non-small cell lung cancer. Cancer Genomics Proteomics 16: 99-119, 2019. PMID: 30850362. DOI: 10.21873/cgp.20116

24 Weidle UH, Birzele F and Nopora A: Pancreatic Ductal Adenocarcinoma: MicroRNAs affecting tumor growth and metastasis in preclinical in vivo models. Cancer Genomics Proteomics 16: 451-464, 2019. PMID: 31659100. DOI: $10.21873 / \operatorname{cgp} .20149$

25 Shi J, Zhang Y, Jin N, Li Y, Wu S and Xu L: MicroRNA-221-3p plays an oncogenic role in gastric carcinoma by inhibiting PTEN expression. Oncol Res 25: 523-536, 2017. PMID: 27712596. DOI: $10.3727 / 096504016 X 14756282819385$

26 Seok JK, Lee SH, Kim MJ and Lee YM: MicroRNA-382 induced by HIF- $1 \alpha$ is an angiogenic miR targeting the tumor suppressor phosphatase and tensin homolog. Nucleic Acids Res 42: 80628072, 2014. PMID: 24914051. DOI: 10.1093/nar/gku515

27 Ma J, Liu J, Wang Z, Gu X, Fan Y, Zhang W, Xu L, Zhang J and Cai D: NF-kappaB-dependent microRNA-425 upregulation promotes gastric cancer cell growth by targeting PTEN upon IL$1 \beta$ induction. Mol Cancer 13:40, 2014. PMID: 24571667. DOI: 10.1186/1476-4598-13-40

28 Wang YN, Xu F, Zhang P, Wang P, Wei YN, Wu C and Cheng SJ: MicroRNA-575 regulates development of gastric cancer by targeting PTEN. Biomed Pharmacother 113: 108716, 2019. PMID: 30844657. DOI: 10.1016/j.biopha.2019.108716

29 Papa A and Pandolfi PP: The PTEN-PI3K axis in cancer. Biomolecules 9(4): 153, 2019. PMID: 30999672. DOI: 10.3390/biom 9040153

30 Lee YR, Chen M and Pandolfi PP: The functions and regulation of the PTEN tumour suppressor: new modes and prospects. Nat Rev Mol Cell Biol 19: 547-562, 2018. PMID: 29858604. DOI: 10.1038/s41580-018-0015-0

$31 \mathrm{He} \mathrm{C}$, Wang L, Zhang $\mathrm{J}$ and $\mathrm{Xu} \mathrm{H}$ : Hypoxia-inducible microRNA-224 promotes the cell growth, migration and invasion by directly targeting RASSF8 in gastric cancer. Mol Cancer 16: 35, 2017. PMID: 28173803. DOI: 10.1186/s12943-017-0603-1

32 Sherwood V, Recino A, Jeffries A, Ward A and Chalmers AD: The N-terminal RASSF family: a new group of Ras-associationdomain-containing proteins, with emerging links to cancer formation. Biochem J 425: 303-311, 2009. PMID: 20025613. DOI: $10.1042 / \mathrm{BJ} 20091318$

33 Lock FE, Underhill-Day N, Dunwell T, Matallanas D, Cooper W, Hesson L, Recino A, Ward A, Pavlova T, Zabarovsky E, Grant MM, Maher ER, Chalmers AD, Kolch W and Latif F: The RASSF8 candidate tumor suppressor inhibits cell growth and regulates the Wnt and NF-kappaB signaling pathways. Oncogene 29: 4307-4316, 2010. PMID: 20514026. DOI: 10.1038/onc. 2010.192

34 Zhang L, Wang JH, Liang RX, Huang ST, Xu J, Yuan LJ, Huang L, Zhou Y, Yu XJ, Wu SY, Luo RZ, Yun JP, Jia WH and Zheng M: RASSF8 downregulation promotes lymphangiogenesis and metastasis in esophageal squamous cell carcinoma. Oncotarget 6: 34510-34524, 2015. PMID: 26439687. DOI: 10.18632/ oncotarget.5923

35 Li C, Lu S and Shi Y: MicroRNA-187 promotes growth and metastasis of gastric cancer by inhibiting FOXA2. Oncol Rep 37: 1747-1755, 2017. PMID: 28098868. DOI: 10.3892/or.2017.5370
36 Zhu CP, Wang J, Shi B, Hu PF, Ning BF, Zhang Q, Chen F, Chen WS, Zhang $\mathrm{X}$ and Xie WF: The transcription factor FOXA2 suppresses gastric tumorigenesis in vitro and in vivo. Dig Dis Sci 60: 109-117, 2015. PMID: 25129104. DOI: 10.1007/s10620-0143290-4

37 Wang Z, Ma X, Cai Q, Wang X, Yu B, Cai Q, Liu B, Zhu Z and Li C: MiR-199a-3p promotes gastric cancer progression by targeting ZHX1. FEBS Lett 588: 4504-4512, 2014. PMID: 25448600. DOI: 10.1016/j.febslet.2014.09.047

38 Ma X, Huang M, Wang Z, Liu B, Zhu Z and Li C: ZHX1 inhibits gastric cancer cell growth through inducing cell-cycle arrest and apoptosis. J Cancer 7: 60-68, 2016. PMID: 26722361. DOI: 10.7150/jca. 12973

39 Liu Y, Ma D and Ji C: Zinc fingers and homeoboxes family in human diseases. Cancer Gene Ther 22: 223-226, 2015. PMID: 25857360. DOI: $10.1038 /$ cgt.2015

40 Li N, Zhang QY, Zou JL, Li ZW, Tian TT, Dong B, Liu XJ, Ge S, Zhu Y, Gao J and Shen L: miR-215 promotes malignant progression of gastric cancer by targeting RUNX1. Oncotarget 7: 4817-4828, 2016. PMID: 26716895. DOI: 10.18632/oncotarget. 6736

41 Xu X, Zhang Y, Liu Z, Zhang X and Jia J: miRNA-532-5p functions as an oncogenic microRNA in human gastric cancer by directly targeting RUNX3. J Cell Mol Med 20: 95-103, 2016. PMID: 26515139. DOI: $10.1111 / \mathrm{jcmm} .12706$

42 Chuang LS, Ito K and Ito Y: RUNX family: Regulation and diversification of roles through interacting proteins. Int J Cancer 132: 1260-1271, 2013. PMID: 23180629. DOI: 10.1002/ ijc. 27964

43 Janes KA: RUNX1 and its understudied role in breast cancer. Cell Cycle 10: 3461-3465, 2011. PMID: 22024923. DOI: 10.4161/cc.10.20.18029

44 Li QL, Ito K, Sakakura C, Fukamachi H, Inoue Ki, Chi XZ, Lee KY, Nomura S, Lee CW, Han SB, Kim HM, Kim WJ, Yamamoto $\mathrm{H}$, Yamashita N, Yano T, Ikeda T, Itohara S, Inazawa J, Abe T, Hagiwara A, Yamagishi H, Ooe A, Kaneda A, Sugimura T, Ushijima T, Bae SC and Ito Y: Causal relationship between the loss of RUNX3 expression and gastric cancer. Cell 109: 113-124, 2002. PMID: 11955451. DOI: 10.1016/s0092-8674(02)00690-6

45 Sakakura C, Hasegawa K, Miyagawa K, Nakashima S, Yoshikawa T, Kin S, Nakase Y, Yazumi S, Yamagishi H, Okanoue T, Chiba T and Hagiwara A: Possible involvement of RUNX3 silencing in the peritoneal metastases of gastric cancers. Clin Cancer Res 11: 6479-6488, 2005. PMID: 16166423. DOI: 10.1158/1078-0432.CCR-05-0729

46 Peng Z, Wei D, Wang L, Tang H, Zhang J, Le X, Jia Z, Li Q and Xie K: RUNX3 inhibits the expression of vascular endothelial growth factor and reduces the angiogenesis, growth, and metastasis of human gastric cancer. Clin Cancer Res 12: 63866394, 2006. PMID: 17085650. DOI: 10.1158/1078-0432.CCR05-2359

47 Chi XZ, Yang JO, Lee KY, Ito K, Sakakura C, Li QL, Kim HR, Cha EJ, Lee YH, Kaneda A, Ushijima T, Kim WJ, Ito Y and Bae SC: RUNX3 suppresses gastric epithelial cell growth by inducing p21(WAF1/Cip1) expression in cooperation with transforming growth factor $\{$ beta\}-activated SMAD. Mol Cell Biol 25: 8097 8107, 2005. PMID: 16135801. DOI: 10.1128/MCB.25.18.80978107.2005

48 Gong J, Cui Z, Li L, Ma Q, Wang Q, Gao Y and Sun H: MicroRNA-25 promotes gastric cancer proliferation, invasion, 
and migration by directly targeting F-box and WD-40 Domain Protein 7, FBXW7. Tumour Biol 36: 7831-7840, 2015. PMID: 25944166. DOI: $10.1007 / \mathrm{s} 13277-015-3510-3$

49 Welcker M and Clurman BE: FBW7 ubiquitin ligase: a tumour suppressor at the crossroads of cell division, growth and differentiation. Nat Rev Cancer 8: 83-93, 2008. PMID: 18094723. DOI: $10.1038 /$ nrc2290

50 Cheng Y and Li G: Role of the ubiquitin ligase Fbw7 in cancer progression. Cancer Metastasis Rev 31: 75-87, 2012. PMID: 22124735. DOI: $10.1007 / \mathrm{s} 10555-011-9330-\mathrm{z}$

51 Cao J, Ge MH and Ling ZQ: Fbxw7 tumor suppressor: A vital regulator contributes to human tumorigenesis. Medicine (Baltimore) 95: e2496, 2016. PMID: 26886596. DOI: 10.1097/MD.0000000000002496

52 Yang G, Gong Y, Wang Q, Wang L and Zhang X1: miR-100 antagonism triggers apoptosis by inhibiting ubiquitinationmediated p53 degradation. Oncogene 36: 1023-1037, 2017. PMID: 27524417. DOI: 10.1038/onc.2016.270

53 Benard G, Neutzner A, Peng G, Wang C, Livak F, Youle RJ and Karbowski M: IBRDC2, an IBR-type E3 ubiquitin ligase, is a regulatory factor for Bax and apoptosis activation. EMBO J 29: 1458-1471, 2010. PMID: 20300062. DOI: 10.1038/emboj.2010.39

54 Ho SR, Mahanic CS, Lee YJ and Lin WC: RNF144A, an E3 ubiquitin ligase for DNA-PKcs, promotes apoptosis during DNA damage. Proc Natl Acad Sci USA 111: E2646-2655, 2014. PMID: 24979766. DOI: 10.1073/pnas.

55 Huang J, Xu LG, Liu T, Zhai Z and Shu HB: The p53-inducible E3 ubiquitin ligase p53RFP induces p53-dependent apoptosis. FEBS Lett 580: 940-947, 2006. PMID: 16427630. DOI: 10.1016/j.febslet.2005.09.105

56 Wang Z, Liu M, Zhu H, Zhang W, He S, Hu C, Quan L, Bai J and $\mathrm{Xu} \mathrm{N}$ : miR-106a is frequently upregulated in gastric cancer and inhibits the extrinsic pathway by targeting FAS. Mol Carcinog 52: 634-646, 2013. PMID: 22431000. DOI: $10.1002 / \mathrm{mc} .21899$

57 Zhu M, Zhang N, He S, Yan R and Zhang J: MicroRNA-106a functions as an oncogene in human gastric cancer and contributes to proliferation and metastasis in vitro and in vivo. Clin Exp Metastasis 33: 509-519, 2016. PMID: 27142596. DOI: 10.1007/ s10585-016-9795-9

58 Igney FH and Krammer PH: Death and anti-death: tumour resistance to apoptosis. Nat Rev Cancer 2: 277-288, 2002. PMID: 12001989. DOI: $10.1038 / \mathrm{nrc} 776$

59 Peter ME, Hadji A, Murmann AE, Brockway S, Putzbach W, Pattanayak A and Ceppi P: The role of CD95 and CD95 ligand in cancer. Cell Death Differ 22: 885-886, 2015. PMID: 25849030. DOI: $10.1038 / \mathrm{cdd} .2015 .25$

60 Ge X, Liu X, Lin F, Li P, Liu K, Geng R, Dai C, Lin Y, Tang W, Wu Z, Chang J, Lu J and Li J: MicroRNA-421 regulated by HIF$1 \alpha$ promotes metastasis, inhibits apoptosis, and induces cisplatin resistance by targeting E-cadherin and caspase-3 in gastric cancer. Oncotarget 7: 24466-24482, 2016. PMID: 27016414. DOI: $10.18632 /$ oncotarget.8228

61 Yu W, Yang L, Li T and Zhang Y: Cadherin signaling in cancer: Its functions and role as a therapeutic target. Front Oncol 9: 989, 2019. PMID: 31637214. DOI: 10.3389/fonc.2019.00989

62 Gloushankova NA, Zhitnyak IY and Rubtsova SN: Role of epithelial-mesenchymal transition in tumor progression. Biochemistry (Mosc) 83: 1469-1476, 2018. PMID: 30878022. DOI: $10.1134 /$ S0006297918120052
63 Zhang F, Li K, Pan M, Li W, Wu J, Li M, Zhao L and Wang H: miR-589 promotes gastric cancer aggressiveness by a LIFRPI3K/AKT-c-Jun regulatory feedback loop. J Exp Clin Cancer Res 37: 152, 2018. PMID: 30012200. DOI: 10.1186/s13046-0180821-4

64 Jones SA and Jenkins BJ: Recent insights into targeting the IL-6 cytokine family in inflammatory diseases and cancer. Nat Rev Immunol 18: 773-789, 2018. PMID: 30254251. DOI: 10.1038/ s41577-018-0066-7

65 Luo Q, Wang C, Jin G1, Gu D, Wang N, Song J, Jin H, Hu F, Zhang Y, Ge T, Huo X, Chu W, Shu H, Fang J, Yao M, Gu J, Cong W1 and Qin W: LIFR functions as a metastasis suppressor in hepatocellular carcinoma by negatively regulating phosphoinositide 3-kinase/AKT pathway. Carcinogenesis 36: 1201-1212, 2015. PMID: 26249360. DOI: $10.1093 /$ carcin/bgv 108

66 Qin S, Ai F, Ji WF, Rao W, Zhang HC andYao WJ: miR-19a promotes cell growth and tumorigenesis through targeting SOCS1 in gastric cancer. Asian Pac J Cancer Prev 14: 835-840, 2013. PMID: 23621248. DOI: 10.7314/apjcp.2013.14.2.835

67 Krebs DL and Hilton DJ: SOCS proteins: negative regulators of cytokine signaling. Stem Cells 19: 378-387, 2001. PMID: 11553846. DOI: $10.1634 /$ stemcells.19-5-378

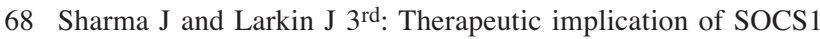
modulation in the treatment of autoimmunity and cancer. Front Pharmacol 10: 324, 2019. PMID: 31105556. DOI: 10.3389/fphar. 2019.00324

69 Morris R, Kershaw NJ and Babon JJ: The molecular details of cytokine signaling via the JAK/STAT pathway. Protein Sci 27: 1984-2009, 2018. PMID: 30267440. DOI: 10.1002/pro.3519

70 Wu Q, Yang Z, Wang F, Hu S, Yang L, Shi Y and Fan D: MiR19b/20a/92a regulates the self-renewal and proliferation of gastric cancer stem cells. J Cell Sci 126: 4220-4229, 2013. PMID: 23868977. DOI: $10.1242 /$ jcs. 127944

71 Wu Z, Zheng S, Li Z, Tan J and Yu Q: E2F1 suppresses Wnt/ßcatenin activity through transactivation of $\beta$-catenin interacting protein ICAT. Oncogene 30: 3979-2984, 2011. PMID: 21532622. DOI: 10.1038/onc.2011.129

72 Louie SH, Yang XY, Conrad WH, Muster J, Angers S, Moon RT, Benjamin NR and Cheyette BNR: Modulation of the beta-catenin signaling pathway by the dishevelled-associated protein Hipk1 PLoS One 4: e4310, 2009. PMID: 19183803. DOI: 10.1371/journal.pone.0004310

73 Jia X, Li N, Peng C, Deng Y, Wang J, Deng M, Lu M, Yin J, Zheng G, Liu H and He Z: miR-493 mediated DKK1 downregulation confers proliferation, invasion and chemo-resistance in gastric cancer cells. Oncotarget 7: 7044-7054, 2016. PMID: 26799283. DOI: 10.18632 /oncotarget.6951

74 Zhan T, Rindtorff N and Boutros M: Wnt signaling in cancer. Oncogene 36: 1461-1473, 2017. PMID: 27617575. DOI: 10.1038/onc.2016.304

75 Molaei F, Forghanifard MM, Fahim Y and Abbaszadegan MR: Molecular signaling in tumorigenesis of gastric cancer. Iran Biomed J 22: 217-230, 2018. PMID: 29706061. DOI: 10.22034 ibj.22.4.217

76 Hong SA, Yoo SH, Lee HH, Sun DS, Won HS, Kim O and Ko $\mathrm{YH}$ : Prognostic value of dickkopf- 1 and $\beta$-catenin expression in advanced gastric cancer. BMC Cancer 18: 506, 2018. PMID: 29720122. DOI: $10.1186 / \mathrm{s} 12885-018-4420-8$

77 Wang L, Li B, Zhang L, Li Q, He Z, Zhang X, Huang X, Xu Z, Xia Y, Zhang Q, Li Q, Xu J, Sun G and Xu Z: miR-664a-3p 
functions as an oncogene by targeting Hippo pathway in the development of gastric cancer. Cell Prolif 52: e12567, 2019. PMID: 30883979. DOI: 10.1111/cpr.12567

78 Harvey KF, Zhang X and Thomas DM: The Hippo pathway and human cancer. Nat Rev Cancer 13: 246-257, 2013. PMID: 23467301. DOI: $10.1038 / \mathrm{nrc} 3458$

79 Meng Z, Moroishi T and Guan KL: Mechanisms of hippo pathway regulation. Genes Dev 30: 1-17, 2016. PMID: 26728553. DOI: $10.1101 / \mathrm{gad} .274027$

80 Moon S, Yeon Park S and Woo Park H: Regulation of the Hippo pathway in cancer biology. Cell Mol Life Sci 75: 2303-2319, 2018. PMID: 29602952. DOI: 10.1007/s00018-018-2804-1

81 Hu X, Wang Y, Liang H, Fan Q, Zhu R, Cui J, Zhang W, Zen K, Zhang CY, Hou D, Zhou Z and Chen X: miR-23a/b promote tumor growth and suppress apoptosis by targeting PDCD4 in gastric cancer. Cell Death Dis 8: e3059, 2017. PMID: 28981115. DOI: $10.1038 /$ cddis.2017

82 Liang H, Wang F, Chu D, Zhang W, Liao Z, Fu Z, Yan X, Zhu $\mathrm{H}$, Guo W, Zhang Y, Guan W and Chen X: miR-93 functions as an oncomiR for the downregulation of PDCD4 in gastric carcinoma. Sci Rep 6: 23772, 2016. PMID: 27021515. DOI: $10.1038 /$ srep 23772

83 Wang W, Zhao J, Wang H, Sun Y, Peng Z, Zhou G, Fan L, Wang $\mathrm{X}$, Yang $\mathrm{S}$, Wang $\mathrm{R}$ and Fang $\mathrm{D}$ : Programmed cell death 4 (PDCD4) mediates the sensitivity of gastric cancer cells to TRAIL-induced apoptosis by down-regulation of FLIP expression. Exp Cell Res 316: 2456-2464, 2010. PMID: 20595005. DOI: $10.1016 /$ j.yexcr.2010.05.027

84 Matsuhashi S, Manirujjaman M, Hamajima H and Ozaki I: Control mechanisms of the tumor suppressor PDCD4: Expression and functions. Int $\mathrm{J}$ Mol Sci 20, 2019. PMID: 31075975. DOI: 10.3390/ijms20092304

85 Ma G, Zhang H, Dong M, Zheng X, Ozaki I, Matsuhashi S and Guo K: Downregulation of programmed cell death 4 (PDCD4) in tumorigenesis and progression of human digestive tract cancers. Tumour Biol 34: 3879-3885, 2013. PMID: 23838800. DOI: $10.1007 / \mathrm{s} 13277-013-0975-9$

86 Guo PT, Yang D, Sun Z and Xu HM: PDCD4 functions as a suppressor for pT2a and pT2b stage gastric cancer. Oncol Rep 29: 1007-1012, 2013. PMID: 23314309. DOI: 10.3892/or.2013.2232

87 Yan LH, Chen ZN, Li-Li, Chen J, Wei WE, Mo XW, Qin YZ, Lin Y and Chen JS: miR-135a promotes gastric cancer progression and resistance to oxaliplatin. Oncotarget 7: 7069970714, 2016. PMID: 27683111. DOI: 10.18632/oncotarget.12208

88 Britschgi A, Trinh E, Rizzi M, Jenal M, Ress A, Tobler A, Fey MF, Helin K and Tschan MP: DAPK2 is a novel E2F1/KLF6 target gene involved in their proapoptotic function. Oncogene 27 : 5706-5716, 2008. PMID: 18521079. DOI: 10.1038/onc.2008.179

89 Tur MK, Daramola AK, Gattenlöhner S, Herling M, Chetty S and Barth S: Restoration of DAP kinase tumor suppressor function: A therapeutic strategy to selectively induce apoptosis in cancer cells using immunokinase fusion proteins. Biomedicines 5: pii: E59, 2017. PMID: 28976934. DOI: 10.3390/biomedicines5040059

90 Huang Y, Chen L, Guo L, Hupp TR and Lin Y: Evaluating DAPK as a therapeutic target. Apoptosis 19: 371-386, 2014. PMID: 24305735. DOI: 10.1007/s10495-013-0919-2

91 Chan AW, Chan MW, Lee TL, Ng EK, Leung WK, Lau JY, Tong JH, Chan FK and To KF: Promoter hypermethylation of deathassociated protein-kinase gene associated with advance stage gastric cancer. Oncol Rep 13: 937-941, 2005. PMID: 15809761.
92 Hsu KW, Fang WL, Huang KH, Huang TT, Lee HC, Hsieh RH, Chi CW and Yeh TS: Notch1 pathway-mediated microRNA-1515p promotes gastric cancer progression. Oncotarget 7: 3803638051, 2016. PMID: 27191259. DOI: 10.18632/oncotarget.9342

93 Lacroix M, Riscal R, Arena G, Linares LK and Le Cam L: Metabolic functions of the tumor suppressor p53: Implications in normal physiology, metabolic disorders, and cancer. Mol Metab, 2019. PMID: 31685430. DOI: 10.1016/j.molmet.2019.10.002

94 Cheok CF and Lane DP: Exploiting the p53 pathway for therapy. Cold Spring Harb Perspect Med 7(3): a026310, 2017. PMID: 28193768. DOI: $10.1101 /$ cshperspect.a026310

95 Zhou L, Liang X, Zhang L, Yang L, Nagao N, Wu H, Liu C, Lin $\mathrm{S}$, Cai G and Liu J: MiR-27a-3p functions as an oncogene in gastric cancer by targeting BTG2. Oncotarget 7: 51943-51954, 2016. PMID: 27409164. DOI: 10.18632/oncotarget.10460

96 Zhang YJ, Wei L, Liu M, Li J, Zheng YQ, Gao Y and Li XR: BTG2 inhibits the proliferation, invasion, and apoptosis of MDAMB-231 triple-negative breast cancer cells. Tumour Biol 34: 1605-1613, 2013. PMID: 23420441. DOI: 10.1007/s13277-0130691-5

97 Zhang L, Huang H, Wu K, Wang M and Wu B: Impact of BTG2 expression on proliferation and invasion of gastric cancer cells in vitro. Mol Biol Rep 37: 2579-2586, 2010. PMID: 19728149. DOI: 10.1007/s11033-009-9777-y

98 Yuniati L, Scheijen B, van der Meer LT and van Leeuwen FN: Tumor suppressors BTG1 and BTG2: Beyond growth control. J Cell Physiol 234: 5379-5389, 2019. PMID: 30350856. DOI: 10.1002/jcp. 27407

99 Yin G, Zhou H, Xue Y, Yao B and Zhao W: MicroRNA-340 promotes the tumor growth of human gastric cancer by inhibiting cyclin G2. Oncol Rep 36: 1111-1118, 2016. PMID: 27374211. DOI: $10.3892 /$ or.2016.4876

100 Bates S, Rowan S and Vousden KH: Characterisation of human cyclin G1 and G2: DNA damage inducible genes. Oncogene 13: 1103-1109, 1996. PMID: 8806701

101 Bennin DA, Don AS, Brake T, McKenzie JL, Rosenbaum H, Ortiz L, DePaoli-Roach AA and Horne MC: Cyclin G2 associates with protein phosphatase $2 \mathrm{~A}$ catalytic and regulatory B' subunits in active complexes and induces nuclear aberrations and a G1/S phase cell cycle arrest. J Biol Chem 277: 27449-27467, 2002. PMID: 11956189. DOI: 10.1074/jbc.M111693200

102 Sun GG, Hu WN, Cui DW and Zhang J: Decreased expression of CCNG2 is significantly linked to the malignant transformation of gastric carcinoma. Tumour Biol 35: 2631-2639, 2014. PMID: 24248541. DOI: $10.1007 / \mathrm{s} 13277-013-1346-2$

103 Chen XL, Hong LL, Wang KL, Liu X, Wang JL, Lei L, Xu ZY, Cheng XD and Ling ZQ: Deregulation of CSMD1 targeted by microRNA-10b drives gastric cancer progression through the NFкB pathway. Int J Biol Sci 15: 2075-2086, 2019. PMID: 31592231. DOI: $10.7150 /$ ijbs.23802

104 Kraus DM, Elliott GS, Chute H, Horan T, Pfenninger KH, Sanford SD, Foster S, Scully S, Welcher AA and Holers VM: CSMD1 is a novel multiple domain complement-regulatory protein highly expressed in the central nervous system and epithelial tissues. J Immunol 176: 4419-4430, 2006. PMID: 16547280. DOI: 10.4049/jimmunol.176.7.4419

105 Tang MR, Wang YX, Guo S, Han SY and Wang D: CSMD1 exhibits antitumor activity in A375 melanoma cells through activation of the Smad pathway. Apoptosis 17: 927-937, 2012. PMID: 22538441. DOI: 10.1007/s10495-012-0727-0 
106 Ma C, Quesnelle KM, Sparano A, Rao S, Park MS, Cohen MA, Wang Y, Samanta M, Kumar MS, Aziz MU, Naylor TL, Weber BL, Fakharzadeh SS, Weinstein GS, Vachani A, Feldman MD and Brose MS: Characterization CSMD1 in a large set of primary lung, head and neck, breast and skin cancer tissues. Cancer Biol Ther 8: 907-916, 2009. PMID: 19276661. DOI: 10.4161/ cbt.8.10.8132

107 Zhou Y, Li R, Yu H, Wang R and Shen Z: microRNA-130a is an oncomir suppressing the expression of CRMP4 in gastric cancer. Onco Targets Ther 10: 3893-3905, 2017. PMID: 28831264. DOI: 10.2147/OTT.S139443

108 Arimura N, Menager C, Fukata Y and Kaibuchi K: Role of CRMP-2 in neuronal polarity. J Neurobiol 58: 34-47, 2004. PMID: 14598368. DOI: 10.1002/neu.10269

109 Tan F, Thiele CJ and Li Z: Collapsin response mediator proteins: Potential diagnostic and prognostic biomarkers in cancers (Review). Oncol Lett 7: 1333-1340, 2014. PMID: 24765134. DOI: $10.3892 / \mathrm{ol} .2014 .1909$

110 Tang MR, Wang YX, Guo S, Han SY and Wang D: CSMD1 exhibits antitumor activity in A375 melanoma cells through activation of the Smad pathway. Apoptosis 71: 927-937, 2012. PMID: 22538441. DOI: 10.1007/s10495-012-0727-0

111 Chen S, Zhang X, Peng J, Zhai E, He Y, Wu H, Chen C, Ma J, Wang $\mathrm{Z}$ and Cai S: VEGF promotes gastric cancer development by upregulating CRMP4. Oncotarget 7: 17074-17086, 2016. PMID: 26934554. DOI: 10.18632/oncotarget.7717

$112 \mathrm{Lu} \mathrm{M}$, Huang Y, Sun W, Li P, Li L and Li L: miR-135b-5p promotes gastric cancer progression by targeting CMTM3. Int J Oncol 52: 589-598, 2018. PMID: 29345297. DOI: 10.3892/ijo.2017.4222

113 Han W, Ding P, Xu M, Wang L, Rui M, Shi S, Liu Y, Zheng Y, Chen Y, Yang T and Ma D: Identification of eight genes encoding chemokine-like factor superfamily members 1-8 (CKLFSF1-8) by in silico cloning and experimental validation. Genomics 81 : 609-617, 2003. PMID: 12782130. DOI: 10.1016/s08887543(03)00095-8

114 Su Y, Lin Y, Zhang L, Liu B, Yuan W, Mo X, Wang X, Li H, Xing X, Cheng X, Dong B, Hu Y, Du H, Zhu Y, Ding N, Li J, Liu W, Ma Y, Qiu X, Ji J and Han W: CMTM3 inhibits cell migration and invasion and correlates with favorable prognosis in gastric cancer. Cancer Sci 105: 26-34, 2014. PMID: 24131472. DOI: $10.1111 /$ cas. 12304

115 Wang Y, Li J, Cui Y, Li T, Ng KM, Geng H, Li H, Shu XS, Li H, Liu W, Luo B, Zhang Q, Mok TS, Zheng W, Qiu X, Srivastava G, Yu J, Sung JJ, Chan AT, Ma D, Tao Q and Han W: CMTM3, located at the critical tumor suppressor locus 16q22.1, is silenced by $\mathrm{CpG}$ methylation in carcinomas and inhibits tumor cell growth through inducing apoptosis. Cancer Res 69: 51945201, 2009. PMID: 19509237. DOI: 10.1158/0008-5472.CAN08-3694

116 Yuan W, Li T, Mo X, Wang X, Liu B, Wang W, Su Y, Xu L and Han W: Knockdown of CMTM3 promotes metastasis of gastric cancer via the STAT3/Twist1/EMT signaling pathway. Oncotarget 7: 29507-29519, 2016. PMID: 27121055. DOI: 10.18632/oncotarget.8789

117 Yuan W, Liu B, Wang X, Li T, Xue H, Mo X, Yang S, Ding S and Han W: CMTM3 decreases EGFR expression and EGFmediated tumorigenicity by promoting Rab5 activity in gastric cancer. Cancer 386: 77-86, 2016. PMID: 27867015. DOI: 10.1016/j.canlet.2016.11.015
118 Lu J, Wu QQ, Zhou YB, Zhang KH, Pang BX, Li L, Sun N, Wang HS, Zhang S, Li WJ, Zheng W and Liu W: Cancer research advance in CKLF-like MARVEL transmembrane domain containing member family (Review). Asian Pac J Cancer Prev 17: 2741-2744, 2016. PMID: 27356683.

119 Hong X, Xu Y, Qiu X, Zhu Y, Feng X, Ding Z, Zhang S, Zhong L, Zhuang Y, Su C, Hong X and Cai J: MiR-448 promotes glycolytic metabolism of gastric cancer by downregulating KDM2B. Oncotarget 7: 22092-22102, 2016. PMID: 26989077. DOI: 10.18632 /oncotarget. 8020

120 Wahlström T and Henriksson MA: Impact of MYC in regulation of tumor cell metabolism. Biochim Biophys Acta 1849: 563-569, 2015. PMID: 25038584. DOI: 10.1016/j.bbagrm.2014.07.004

121 Yan M, Yang X, Wang H and Shao Q: The critical role of histone lysine demethylase KDM2B in cancer. Am J Transl Res 10: 2222-2233, 2018. PMID: 30210666.

122 Yang X, Wang M, Lin B, Yao D, Li J, Tang X, Li S, Liu Y, Xie R, Yu S: miR-487a promotes progression of gastric cancer by targeting TIA1. Biochimie 154: 119-126, 2018. PMID: 30144499. DOI: 10.1016/j.biochi.2018.08.006

123 Bauer WJ, Heath J, Jenkins JL and Kielkopf CL: Three RNA recognition motifs participate in RNA recognition and structural organization by the pro-apoptotic factor TIA-1. J Mol Biol 415: 727-740, 2012. PMID: 22154808. DOI: 10.1016/j.jmb. 2011.11.040

124 Suswam EA, Li YY, Mahtani H and King PH: Novel DNAbinding properties of the RNA-binding protein TIAR. Nucleic Acids Res 33: 4507-4518, 2015. PMID: 16091628. DOI: 10.1093/nar/gki763

125 Ferrara N, Houck KA, Jakeman LB, Winer J and Leung DW: The vascular endothelial growth factor family of polypeptides. J Cell Biochem 47: 211-218, 1991. PMID: 1791185. DOI: $10.1002 / \mathrm{jcb} .240470305$

126 Izquierdo JM and Valcárcel J: Two isoforms of the T-cell intracellular antigen 1 (TIA-1) splicing factor display distinct splicing regulation activities. Control of TIA-1 isoform ratio by TIA-1-related protein. J Biol Chem 282: 19410-19417, 2007. PMID: 17488725. DOI: 10.1074/jbc.M700688200

127 Venables JP: Unbalanced alternative splicing and its significance in cancer. Bioessays 28: 378-386, 2006. PMID: 16547952. DOI: 10.1002/bies.20390

128 Eberhardt W, Doller A, Akool el-S and Pfeilschifter J: Modulation of mRNA stability as a novel therapeutic approach. Pharmacol Ther 114: 56-73, 2007. PMID: 17320967. DOI: 10.1016/j.pharmthera.2007.01.002

129 Lam JK, Chow MY, Zhang Y, Leung SW: siRNA versus miRNA as therapeutics for gene silencing. Mol Ther Nucleic Acids 4: e252, 2015. PMID: 26372022. DOI: 10.1038/mtna. 2015.23

130 Nguyen DD and Chang S.: Development of novel therapeutic agents by inhibition of oncogenic microRNAs. Int J Mol Sci 19: pii: E65, 2017. PMID: 29280958. DOI: 10.3390/ijms19010065

131 Vester B and Wengel J: LNA (Locked Nucleic Acid): Highaffinity targeting of complementary RNA and DNA Biochemistry 43: 13233-13241, 2004. PMID: 15491130. DOI: 10.1021/bi0485732

$132 \mathrm{Oh} \mathrm{SY,} \mathrm{Ju} \mathrm{Y,} \mathrm{Kim} \mathrm{S} \mathrm{and} \mathrm{Park} \mathrm{H:} \mathrm{PNA-based} \mathrm{antisense}$ oligonucleotides for micrornas inhibition in the absence of a transfection reagent. Oligonucleotides 20: 225-230, 2010. PMID: 20946011. DOI: 10.1089/oli.2010.0238 
133 Di Giorgio A, Tran TPA 1 and Duca M: Small-molecule approaches toward the targeting of oncogenic miRNAs: Roadmap for the discovery of RNA modulators. Future Med Chem 8: 803816, 2016. PMID: 27149207. DOI: 10.4155/fmc-2016-0018

134 Biao Liu B, Childs-Disney JL, Znosko BM, Wang D, Fallahi M, Gallo SM and Disney MD: Analysis of secondary structural elements in human microRNA hairpin precursors. BMC Bioinformatics 17: 112, 2016. PMID: 26928172. DOI: 10.1186/ s12859-016-0960-6

135 Thomas JR and Hergenrother PJ: Targeting RNA with small molecules. Chem Rev 108: 1171-1224, 2008. PMID: 18361529. DOI: $10.1021 / \mathrm{cr} 0681546$

136 Haga CL, Velagapudi SP, Childs-Disney J, Strivelli J, Disney MD and Phinney DG: Rapid generation of miRNA inhibitor leads by bioinformatics and efficient high-throughput screening methods. Methods Mol Biol 1517: 179-198, 2017. PMID: 27924483. DOI: 10.1007/978-1-4939-6563-2_13

137 Chen L, Zhang K, Shi Z, Zhang A, Jia Z, Wang G, Pu P, Kang $\mathrm{C}$ and Lei L: A lentivirus-mediated miR-23b sponge diminishes the malignant phenotype of glioma cells in vitro and in vivo. Oncol Rep 31: 1573-1580, 2014. PMID: 24503899. DOI: 10.3892/or.2014.3012

138 Mali P, Esvelt KM and Church GM: Cas9 as a versatile tool for engineering biology. Nat Methods 10: 957-963, 2013. PMID: 24076990. DOI: 10.1038/nmeth.2649

139 Chang $\mathrm{H}$, Yi B, Ma R, Zhang $\mathrm{X}$, Zhao $\mathrm{H}$ and $\mathrm{Xi}$ Y: CRISPR/cas9, a novel genomic tool to knock down microRNA in vitro and in vivo. Sci Rep 6: 22312, 2016. PMID: 26924382. DOI: $10.1038 /$ srep22312

140 Nosova AS, Koloskova OO, Nikonova AA, Simonova VA, Smirnov VV, Kudlay D and Khaitov MR: Diversity of PEGylation methods of liposomes and their influence on RNA delivery. Medchemcomm 10: 369-377, 2019. PMID: 31015904. DOI: $10.1039 / \mathrm{c} 8 \mathrm{md} 00515 \mathrm{j}$

141 Neuberg P and Kichler A: Recent developments in nucleic acid delivery with polyethylenimines. Adv Genet 88: 263-288, 2014. PMID: 25409609. DOI: 10.1016/B978-0-12-800148-6.00009-2

142 Dufès C, Uchegbu IF and Schätzlein AG: Dendrimers in gene delivery. Adv Drug Deliv Rev 57: 2177-2202, 2005. PMID: 16310284. DOI: 10.1016/j.addr.2005.09.017

143 Shcharbin D, Shakhbazau A and Bryszewska M: Poly(amidoamine) dendrimer complexes as a platform for gene delivery. Expert Opin Drug Deliv 10: 1687-1698, 2013. PMID: 24168461. DOI: $10.1517 / 17425247.2013 .853661$

144 Videira M, Arranja A, Rafael D and Gaspar R: Preclinical development of siRNA therapeutics: towards the match between fundamental science and engineered systems. Nanomedicine 10: 689-702, 2014. PMID: 24333589. DOI: 10.1016/j.nano.2013. 11.018

145 Davis ME and Brewster ME: Cyclodextrin-based pharmaceutics: past, present and future. Nat Rev Drug Discov 3: 1023-1035, 2004. PMID: 15573101 . DOI: $10.1038 /$ nrd1576

146 Ozpolat B, Sood AK and Lopez-Berestein G: Liposomal siRNA nanocarriers for cancer therapy. Adv Drug Deliv Rev 66: 110116, 2014. PMID: 24384374. DOI: 10.1016/j.addr.2013.12.008

147 Ozpolat B, Sood AK and Lopez-Berestein G: Liposomal siRNA nanocarriers for cancer therapy. Adv Drug Deliv Rev 66: 110116, 2014. PMID: 24384374. DOI: 10.1016/j.addr.2013.12.008

148 Prakash TP, Graham MJ, Yu J, Carty R, Low A, Chappell A, Schmidt K, Zhao C, Aghajan M, Murray HF, Riney S, Booten
SL, Murray SF, Gaus H, Crosby J, Lima WF, Guo S, Monia BP, Swayze EE and Seth PP: Targeted delivery of antisense oligonucleotides to hepatocytes using triantennary $\mathrm{N}$-acetyl galactosamine improves potency 10 -fold in mice. Nucleic Acids Res 42: 8796-8807, 2014. PMID: 24992960. DOI: 10.1093/nar/ gku531

149 MacLeod AR and Crooke ST: RNA therapeutics in oncology: Advances, challenges, and future directions. J Clin Pharmacol 57(Suppl 10): S43-S59, 2017. PMID: 21525952. DOI: 10.1038/ gt. 2011.50

$150 \mathrm{Li} \mathrm{Z}$ and Rana TM: Therapeutic targeting of microRNAs: Current status and future challenges. Nat Rev Drug Discov 13: 622-638, 2014. PMID: 25011539. DOI: $10.1038 /$ nrd4359

151 Garofalo M, Leva GD and Croce CM: MicroRNAs as anti-cancer therapy. Curr Pharm Des 20: 5328-5335, 2014. PMID: 24479801. DOI: $10.2174 / 1381612820666140128211346$

152 Malek A, Merkel O, Fink L, Czubayko F, Kissel T and Aigner A: In vivo pharmacokinetics, tissue distribution and underlying mechanisms of various PEI(-PEG)/siRNA complexes. Toxicol Appl Pharmacol 236: 97-108, 2009. PMID: 19371615. DOI: 10.1016/j.taap.2009.01.014

153 Wang AZ, Langer R and Farokhzad OC: Nanoparticle delivery of cancer drugs. Annu Rev Med 63: 185-198, 2012. PMID: 21888516. DOI: 10.1146/annurev-med-040210-162544

154 Rozema DB, Lewis DL, Wakefield DH, Wong SC, Klein JJ, Roesch PL, Bertin SL, Reppen TW, Chu Q, Blokhin AV, Hagstrom JE and Wolff JA: Dynamic PolyConjugates for targeted in vivo delivery of siRNA to hepatocytes. Proc Natl Acad Sci USA 104: 12982-12987, 2007. PMID: 17652171. DOI: 10.1073/pnas.0703778104

155 Kanasty R, Dorkin JR, Vegas A and Anderson D: Delivery materials for siRNA therapeutics. Nat Mater 12: 967-977, 2013. PMID: 24150415. DOI: 10.1038/nmat3765

156 Zhang L, Liao Y and Tang L3: MicroRNA-34 family: a potential tumor suppressor and therapeutic candidate in cancer. J Exp Clin Cancer Res 38: 53, 2019. PMID: 30717802. DOI: 10.1186/ s13046-019-1059-5

157 Shah MY, Ferrajoli A, Sood AK, Lopez-Berestein G and Calin GA: microRNA therapeutics in cancer - an emerging concept. EBioMedicine 12: 34-42, 2016. PMID: 27720213. DOI: 10.1016/j.ebiom.2016.09.017

158 van Zandwijk N, Pavlakis N, Kao SC, Linton A, Boyer MJ, Clarke S, Huynh Y, Chrzanowska A, Fulham MJ, Bailey DL, Cooper WA, Kritharides L, Ridley L, Pattison ST, MacDiarmid J, Brahmbhatt H and Reid G: Safety and activity of microRNAloaded minicells in patients with recurrent malignant pleural mesothelioma: a first-in-man, phase 1, open-label, doseescalation study. Lancet Oncol 18: 1386-1396, 2017. PMID: 28870611. DOI: 10.1016/S1470-2045(17)30621-6

159 Pekarsky Y, Balatti V and Croce CM: BCL2 and miR-15/16: from gene discovery to treatment. Cell Death Differ 25: 21-26, 2018. PMID: 31745319. DOI: 10.1038/cdd.2017.159

160 Witten L and Slack FJ: miR-155 as a novel clinical target for hematological malignancies. Carcinogenesis 41: 2-7, 2020. PMID: 31711135. DOI: 10.1093/carcin/bgz183

Received September 1, 2020

Revised October 2, 2020

Accepted October 5, 2020 